\title{
ЯКІСТЬ ОСВІТИ - ПОКАЗНИК ВІДПОВІДАЛЬНОСТІ ПЕРЕД СУСПІЛЬСТВОМ
}

\author{
Ю. М. Колесник, Ю. М. Нерянов, В. М. Компанієць \\ Запорізький державний медичний університет
}

\section{EDUCATION QUALITY IS THE EVIDENCE OF CIVIL RESPONSIBILITY \\ Yu. M. Kolesnyk, Yu. M. Neryanov, V. M. Kompaniyets \\ Zaporizhian State Medical University}

\begin{abstract}
Серед ключових питань медичної освіти її якість займає фундаментальне місце. Вона вимагає балансу між нововведеннями і традиціями, академічними перевагами і соціальною необхідністю, зв'язністю програм і свободою вибору студентів. Шлях у майбутнє може полягати тільки в розробці на європейському рівні механізмів для взаємного прийняття результатів забезпечення якості.

Головним завданням, метою навчання с не копіювання, репродукція, відтворення матеріалу, а навчання навичкам самостійної творчої роботи.

Не слід сліпо копіювати методику і стандарти, пропоновані Болонською декларацісю. У будь-якій ситуації треба виходити 3 національних інтересів і не втрачати здатність до критичної оцінки.

Education quality takes basic place among key problems of medical education. It requires balance between innovations and traditions, academic advantages and social needs, programs connectedness and students' freedom of choice. The only way to the future is the development of mechanisms for mutual taking of results of quality ensuring on European level. The main task and aim of education are not copying, reproduction of material, but training and development of habits of independent creative work.

Methods and standards proposed by Bologna Declaration should not be followed blindfold. The solution of any problem must be found out taking into account national interests and keeping the ability to criticism.
\end{abstract}

Вступ. Принцип освіти як відповідальності перед суспільством припускає те, що Зона європейської вищої освіти повинна будуватися на європейських традиціях відповідальності освіти перед суспільством; на широкому і відкритому доступі як до додипломного, так і післядипломного навчання; на освіті для розвитку особистості і навчанні протягом усього життя; на громадянськості як короткострокової, так і довгострокової соціальної доцільності. Після доступності освіти забезпечення якості освіти - друге за значущістю завдання, яке стоїть перед нами. І у рамках рішення цього завдання необхідно створювати і розвивати вже наявну систему атестації і контролю якості.

Основна частина. Серед ключових питань забезпечення якості медичної освіти необхідно звернути особливу увагу на деякі моменти.

Якість як фундаментальний камінь формування, як основна умова для довіри, доцільності, мобільності, сумісності і привабливості в Зоні європейської вищої освіти. Оцінка якості повинна враховувати цілі і місію університетів і програм; вона вимагає балансу між нововведеннями і традиціями, академічними перевагами і соціально-економічною необхідністю або доцільністю, зв'язністю програм і свободою вибору студентів. Вона повинна охоплювати викладання i наукову діяльність так само, як управління і адміністрування, сприйнятливість до потреб студентів і забезпечення позанавчальних послуг.

Забезпечення якості не може грунтуватися на єдиному переконанні по використанню загального набору стандартів. Шлях в майбутнє може полягати тільки в розробці на європейському рівні механізмів для взаємного прийняття результатів забезпечення якості, що припускає наявність різних їх форм. Такі механізми повинні шанувати наші національні, вузівські, лінгвістичні і дисциплінарні відмінності.

Слід зазначити, що в структурі впровадження Болонського процесу не передбачається створення повністю ідентичних систем освіти в різних країнах, проте ми маємо ситуацію втрати ідентичності української системи освіти.

Разом з цим спостерігається тенденція відмови від фундаментальних напрацювань і традицій вітчизняної освіти. Адже життєздатним залишається факт про те, що вітчизняна медична освіта завжди відрізнялася фундаментальною глибиною знань. 
Сумісність з європейським ринком праці повинна по-різному відбиватися в програмах, залежно від того, коли отримуються знання, уміння і навички, необхідні для роботи. Можливість працевлаштування з урахуванням перспективи навчання протягом усього життя буде досягнута краще через цінності, властиві якісній освіті; через різноманітність підходів і профілів дисциплін; через гнучкість програм, що дозволяють мати багато можливостей входження “в” і виходу “з” них; через розвиток навичок міжспеціалізацій i умінь; через здатність мобілізувати отримані знання, вирішувати проблеми, працювати в команді і розвиватися соціально. Якість підготовки фахівців визначається не тривалістю або змістом навчання, а саме знаннями, вміннями і навичками, отриманими випускниками.

Сьогодні наш диплом не визнається в Європі, незважаючи на приєднання до Болонської декларації. Наші фахівці без додаткового перенавчання не можуть влаштуватися на роботу за фахом. I хоча вони за багатьма показниками, за загальним розвитком, ерудованістю, спеціальною підготовленістю перевершують зарубіжних фахівців, дискредитація українського диплома триває.

Найбільше не влаштовує закордонних працедавців в підготовці наших фахівців низька дієвість знань. Дієвість - це здатність використовувати отримані знання, уміння на практиці. За експертними оцінками, за цим параметром ми поступаємося найбільше.

У нашій сучасній педагогічній практиці метод навчання можна охарактеризувати як репродуктивний метод подачі навчального матеріалу. Основна функція репродуктивного методу навчання - засвоєння навчального матеріалу в ході лекцій з метою його подальшого відтворення і практичного закріплення на практичних і семінарських заняттях. Кінцевою метою $є$ семестровий контроль, який виявляє міру засвоєння матеріалу студентом. Численні наукові експерименти показали низьку ефективність репродуктивного методу. Стресова ситуація при проведенні підсумкового контролю, будь то іспит або модульний контроль, зазубрювання, нескінченне тестування, тобто переклад засвоєного навчального матеріалу 3 довготривалої пам'яті в короткочасний регістр відтворення, призводить до недостатньо високого відсотка залишкових знань у студентів. Простіше кажучи, студент, отримавши жадану оцінку, стирає 3 пам'яті непотрібну вже йому інформацію, а разом 3 нею і образ екзаменатора. Цю ситуацію добре відбивають підсумки “Крок 1", на відміну від показників “Крок 2”, при складанні якого більшою мірою відби- вається професіональна, спеціальна підготовленість випускника, коли треба мати уміння аналізувати i узагальнювати набуті знання.

Інший метод навчання - креативний (творчий), припускає певний ступінь свободи. Особа, яка навчається, повина сама приймати рішення і створювати щось нове на основі отриманих від викладача знань і навичок. Головним завданням, метою навчання є не копіювання, репродукція, відтворення матеріалу, а навчання навичкам самостійної творчої роботи.

У нашій системі освіти креативний метод навчання не набув розповсюдження в силу як об' єктивних чинників (дефіцит грошових коштів, відсутність необхідних матеріальних фондів і тому подібне), так i суб'єктивних обставин.

Обидва ці типи навчання - креативний і репродуктивний, при усій своїй несхожості вимагають пошуку їх єдності, деякої основи, яка могла б їх об'єднати. Україна реформує систему освіти, у тому числі і вищої медичної, адаптує методику викладання до західних стандартів в контексті руху усієї держави в Європейську спільноту. Цей процес стає тим більше актуальним у зв' язку з реформуванням системи охорони здоров'я, що проводиться в нашій країні.

Проблема єдності репродуктивного і креативного підходу до навчання студентів може вирішуватися таким чином.

По-перше, на початковому етапі студенти слухають курс лекцій предмета (предметів), що вивчається, знайомляться з конкретним змістом тієї або іншої навчальної дисципліни. I як експеримент в ЗДМУ така форма впроваджена для спеціальності “Стоматологія".

По-друге, на старших курсах (4-5 - для фармацевтичного, 5-6 - для медичних факультетів) найбільш обдаровані студенти повинні виділятися в окремий потік і їм пропонується індивідуальна форма навчання. Їх підготовка починає набувати творчого характеру - активна участь в науковій роботі тієї або іншої кафедри, написання наукових статей, вирішення актуальної проблеми або завдання. Студент отримує наукового керівника, який коригує творчий пошук студента в заданому напрямі. Спілкування викладача і студента переходить від контролю до співпраці - заохочується самостійна робота студента і його творчий потенціал.

По-третє, виникає необхідність в тому, щоб форма контролю студентів (той же модульний контроль) носила в корені відмінний характер і була орієнтована на творчу діяльність свідомості, а не на відтво- 
рення (зазубрювання) матеріалу. Відпадає необхідність в шпаргалках різної модифікації, оскільки перевіряється в першу чергу робота мислення, творча здатність аналізувати, систематизувати, модифікувати матеріал, отриманий раніше, тобто виробляти щось нове, а не відтворювати старе і давно засвоєне.

Проте слід звернути увагу на той факт, що разом 3 позитивними моментами цій системі властивий і ряд негативних особливостей.

По-перше, зайва формалізація форм контролю: тестування нівелює особу, зводить творчу природу мислення до положення придатка машини, яка оцінює коефіцієнт інтелекту студента і ставить йому оцінку, яка частенько не відбиває його здатності і можливості до креативного мислення. Студент вчиться не заради знань, а заради рейтингу або отримання стипендії, а це ніяк не сприяє позитивній мотивації до отримання знань.

По-друге, масовість набору в студенти призводить до “розмивання" творчих основ особи - знову ж таки відсутній стимул добре вчитися.

По-третє, недостатність фундаментальних знань в галузігуманітарних і природничо-наукових дисциплін призводить до зниження світоглядного і наукового кругозору студентів і сприяє перетворенню на "однобічну” людину. В цілому така система освіти оріє-

\section{Література}

1. Суліма Є. Невідкладні завдання системи вищої освіти на новому етапі Болонського процесу / Є. Суліма // Вища школа. -2010.-№ 11.-С.5-13.

2. Тимошенко О. Організація та управління якістю освіти : проблемні підходи / О. Тимошенко // Вища освіта України.-2010.-№ 1.-С.60-66.

3. Колесник Ю. М. Система управління якістю освіти необхідна складова конкурентноспроможності вітчизняних фахівців / Ю. М. Колесник, Ю. М. Нерянов, В. М. Компанієць // Вища освіта України.-- 2011. - № 3, том II (27).C.240-247. нтована на переформовування людини-студента: він повинен мати набір позитивних якостей у сфері спеціалізації і, як всякий продукт виробництва, мати попит на ринку праці. Тому навряд чи ця система здатна створювати творчих осіб в масовому порядку для цього має бути іншим соціальне місце існування.

Ми повинні враховувати цей чинник при реформуванні системи не лише медичної освіти, але і медицини в цілому. Ось чому, ймовірно, не слід сліпо копіювати методику і стандарти, пропоновані Болонською декларацією. У будь-якій ситуації треба виходити з національних інтересів і не втрачати здатність до критичної оцінки.

Висновки. Україна дійсно повинна продовжувати реформувати систему медичної освіти, оскільки це диктують як зовнішні (інтеграція в Свропу), так і внутрішні (економічні і соціальні) чинники.

Наша держава не повинна сліпо копіювати західні стандарти у сфері вищої медичної освіти. Треба виходити з національних інтересів і не втрачати здатність до критичної оцінки.

Необхідно ретельно перевіряти пропоновані нам методологію і напрацювання у сфері вищої освіти. Ми повинні виробити власну “технологію болонізації”, щоб не стати сировинним придатком ЄС і охоронцем чужих національних інтересів, ігноруючи власну стратегію розвитку та історичні перспективи.

4. Артамонова М. В. Реформа высшей школы и Болонский процесс в России (частный взгляд методиста) / М. В. Артамонова. - Москва : Экономика, 2008. - 280 с.

5. Завдання вищої медичної освіти в контексті реформування галузі / Р. О. Моісеєнко, В. В. Вороненко, І. І. Фещенко [та ін.] // Ваше Здоров’я. - № 31.

6. Семиноженко В. Образование и национальные интересы : выбор траектории. - http:www.semynozhenko.net

7. Поставная Т. А. Болонский процесс в Украине [Електронний ресурс].--Електронні дані. 2007. 